\title{
Association of proton pump inhibitor use with disease burden and cardiometabolic profile among patients hospitalized for acute myocardial infarction
}

\author{
(D)Admira Bilalić', \\ (iD) Josip Anđelo \\ Borovac $^{2,3 *}$, \\ (DTina Tičinović Kurir², \\ (D)Marko Kumrić \\ (D)Andrija Matetić1, \\ (D) Joško Božić ${ }^{2}$ \\ 'University Hospital Centre \\ Split, Split, Croatia \\ 2University of Split School of \\ Medicine, Split, Croatia \\ ${ }^{3}$ Institute of Emergency \\ Medicine of Split-Dalmatia \\ County, Split, Croatia
}

\begin{abstract}
KEYWORDS: acute coronary syndrome, acute myocardial infarction, IPP, proton pump inhibitors, outcomes CITATION: Cardiol Croat. 2021;16(1-2):5. | https://doi.org/10.15836/ccar2021.5

*ADDRESS FOR CORRESPONDENCE: Josip Anđelo Borovac, Klinički bolnički centar Split, Spinčićeva 1, HR-21000 Split, Croatia. / Phone: +385-92-172-1314 / E-mail: jborovac@mefst.hr

ORCID: Admira Bilalić, https://orcid.org/0000-0001-6204-1260 • Josip Anđelo Borovac, https://orcid.org/0000-0002-4878-8146 Tina Tičinović Kurir, https://orcid.org/0000-0001-5975-5393 • Marko Kumrić, https://orcid.org/0000-0002-9696-3359 Andrija Matetić, https://orcid.org/0000-0001-9272-6906 • Joško Božić, https://orcid.org/0000-0003-2649-0936
\end{abstract}

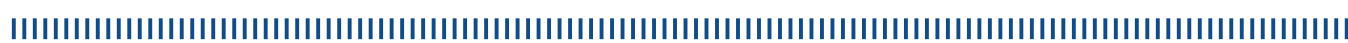

Introduction: Previous studies showed an increased likelihood and risk of acute myocardial infarction (AMI) and hospitalizations for cardiovascular events among patients exposed to chronic use of proton pump inhibitors (PPIs).-3 In this study we aimed to compare parameters reflecting disease burden and cardiometabolic profile among patients treated for AMI with respect to the chronic exposure to PPIs.

Patients and Methods: Data of 143 adult consecutive patients hospitalized for ST-elevation myocardial infarction (STEMI) or non-ST-segment elevation myocardial infarction (NSTEMI) during the 2019-2020 period were analyzed. All continuous variables had a normal distribution.

TABLE 1. Comparison of consecutive patients with acute myocardial infarction exposed to chronic inhibitor of proton pump (IPP) use (IPP+ group) with those not exposed (IPP-group).

\begin{tabular}{|c|c|c|c|}
\hline Variable & IPP+ group $(\mathrm{N}=19)$ & IPP- group ( $N=124)$ & p-value \\
\hline Age, years & $71.9 \pm 9.6$ & $63.3 \pm 11.2$ & $0.003^{*}$ \\
\hline Body mass index, $\mathrm{kg} / \mathrm{m}^{2}$ & $26.2 \pm 1.7$ & $27.3 \pm 3.4$ & 0.201 \\
\hline Waist-to-hip ratio & $1.03 \pm 0.07$ & $1.12 \pm 0.88$ & 0.644 \\
\hline Male sex & $64.7 \%$ & $81.9 \%$ & 0.100 \\
\hline NSTEMI as a type of ACS & $47.4 \%$ & $33.1 \%$ & 0.224 \\
\hline Mean Killip class & $1.11 \pm 0.33$ & $1.10 \pm 0.40$ & 0.890 \\
\hline Mean number of diseased vessels & $1.20 \pm 0.44$ & $1.17 \pm 0.50$ & 0.823 \\
\hline Left ventricular ejection fraction, $\%$ & $50.8 \pm 12.7$ & $52.1 \pm 9.8$ & 0.656 \\
\hline$\Delta$ cardiac Troponin I value, $n g / L q$ & $4726 \pm 5938$ & $2554 \pm 3480$ & $0.025^{\star}$ \\
\hline C-reactive protein, $m g / L$ & $27.4 \pm 48.5$ & $11.7 \pm 20.0$ & $0.015^{*}$ \\
\hline Glucose, $\mathrm{mmol} / \mathrm{L}$ & $9.5 \pm 4.8$ & $7.7 \pm 3.0$ & $0.037^{\star}$ \\
\hline Creatinine, $\mu \mathrm{mol} / \mathrm{L}$ & $110 \pm 56$ & $89 \pm 26$ & $0.012^{\star}$ \\
\hline Sodium, $\mathrm{mmol} / \mathrm{L}$ & $138 \pm 2.9$ & $137 \pm 3.0$ & 0.146 \\
\hline Potassium, $\mathrm{mmol} / \mathrm{L}$ & $4.04 \pm 0.43$ & $4.08 \pm 0.40$ & 0.724 \\
\hline GRACE score, points & $132 \pm 23$ & $114 \pm 26$ & $0.008^{*}$ \\
\hline
\end{tabular}

ACS-acute coronary syndrome; AMI-acute myocardial infarction; GRACE-Global Registry of Acute Coronary Events; NSTEMI-Non-ST-segment elevation myocardial infarction.

*result significant at a two-tailed $p$-value $<0.05$

Thigh-sensitivity cardiac troponin I assay, mean difference from $1^{\text {st }}$ to $2^{\text {nd }}$ measurement

RECEIVED:

November 26, 2020

ACCEPTED:

December 18, 2020

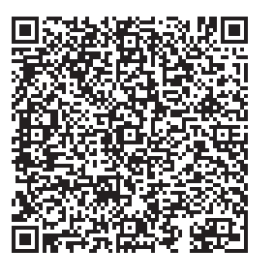

Results: The mean age was $64.8 \pm 11.3$ years and $79.7 \%$ were men. Two-thirds (65.7\%) of patients had STEMI while $34.3 \%$ had NSTEMI. The mean GRACE score in the whole cohort was $117 \pm 26$ points while $12.6 \%$ of patients were at high risk of in-hospital death, after adjustment for the ACS type. A total of 19 IPP+ patients were identified. Patients in the IPP+ group were significantly older and had a higher prevalence of NSTEMI compared to IPP- group while both groups did not significantly differ in terms of sex, body mass index, waist-to-hip ratio the mean number of diseased vessels at angiography, and left ventricular ejection fraction. Patient IPP+ group had a significantly higher high-sensitivity cardiac troponin I rise from $1^{\text {st }}$ to $2^{\text {nd }}$ measurement compared to IPP- group ( $4726 \pm 5938$ vs. 2554 $\pm 3480 \mathrm{ng} / \mathrm{L}, \mathrm{p}=0.025$, Table 1). Furthermore, C-reactive protein, blood glucose, and serum creatinine levels at admission were significantly higher in IPP+ vs. the IPP- group. Finally, patients in the IPP+ group had a significantly higher risk of in-hospital and 6-month post-discharge death compared to IPP- group, as adjudicated by the GRACE score (132 \pm 23 vs. $114 \pm 26$ points, $\mathrm{p}=0.008$ )

Conclusions: Our study showed that AMI patients with chronic exposure to IPPs are older, mostly male, and tend to present with NSTEMI. These patients exhibit a larger magnitude of myocardial injury and systemic inflammation accompanied by worse renal function, and also seem to be at an increased risk of poor in-hospital and post-discharge outcomes. However, potential confounding of underlying comorbidities and age must be taken into account when interpreting these results.

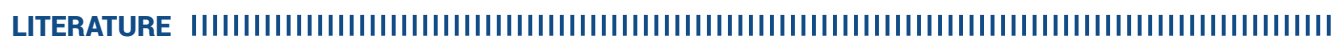

1. Shih CJ, Chen YT, Ou SM, Li SY, Chen TJ, Wang SJ. Proton pump inhibitor use represents an independent risk factor for myocardial infarction. Int J Cardiol. 2014 Nov 15;177(1):292-7. https://doi.org/10.1016/j.ijcard.2014.09.036

2. Tan JM, Parsons R, Sim TF, Lee YP. The Association between Proton Pump Inhibitors and Myocardial Infarction: What Do Food and Drug Administration Data Tell Us? J Res Pharm Pract. 2019 oct 16;8(3):123-128. https://doi.org/10.4103/jrpp.JRPP_19_73

3. Casula M, Scotti L, Galimberti F, Mozzanica F, Tragni E, Corrao G, et al. Use of proton pump inhibitors and risk of ischemic events in the genera population. Atherosclerosis. 2018 0ct;277:123-129. https://doi.org/10.1016/j.atherosclerosis.2018.08.035 